\title{
Hops (Humulus lupulus L.) as a Novel Multipurpose Crop for the Mediterranean Region of Europe: Challenges and Opportunities of Their Cultivation
}

\author{
Francesco Rossini ${ }^{1}\left(\mathbb{D}\right.$, Giuseppe Virga ${ }^{2}$, Paolo Loreti ${ }^{1}$, Nicolò Iacuzzi ${ }^{3, *} \mathbb{D}$, Roberto Ruggeri ${ }^{1, *(\mathbb{D})}$ and \\ Maria Elena Provenzano ${ }^{1}$
}

check for

updates

Citation: Rossini, F.; Virga, G.; Loreti,

P.; Iacuzzi, N.; Ruggeri, R.;

Provenzano, M.E. Hops (Humulus

lupulus L.) as a Novel Multipurpose

Crop for the Mediterranean Region of

Europe: Challenges and

Opportunities of Their Cultivation.

Agriculture 2021, 11, 484. https://

doi.org/10.3390/agriculture11060484

Academic Editor: Gaetano Pandino

Received: 5 April 2021

Accepted: 20 May 2021

Published: 24 May 2021

Publisher's Note: MDPI stays neutral with regard to jurisdictional claims in published maps and institutional affiliations.

Copyright: (c) 2021 by the authors. Licensee MDPI, Basel, Switzerland. This article is an open access article distributed under the terms and conditions of the Creative Commons Attribution (CC BY) license (https:/ / creativecommons.org/licenses/by/ $4.0 /)$
1 Department of Agriculture and Forest Science (DAFNE), University of Tuscia, Via San Camillo de Lellis, 01100 Viterbo, Italy; rossini@unitus.it (F.R.); info@drpagronomia.it (P.L.); provenzano.mariaelena@gmail.com (M.E.P.)

2 Research Consortium for the Development of Innovative Agro-Environmental Systems (Corissia), Via della Libertà 203, 90143 Palermo, Italy; giuseppe.virga@corissia.it

3 Department of Agricultural, Food and Forest Sciences, Università Degli Studi di Palermo, Viale delle Scienze 13, Building 4, 90128 Palermo, Italy

* Correspondence: nicolo.iacuzzi@unipa.it (N.I.); r.ruggeri@unitus.it (R.R.); Tel.: +39-0761-357561 (R.R.)

Abstract: The common hop (Humulus lupulus L.) is a dioecious perennial climbing plant, mainly known for the use of its female inflorescences (cones or, simply, "hops") in the brewing industry. However, the very first interest towards hops was due to its medicinal properties. Actually, the variety of compounds present in almost all plant parts were (and still are) used to treat or prevent several ailments and metabolic disorders, from insomnia to menopausal symptoms as well as obesity and even cancer. Although hops are predominantly grown for hopping beer, the increasing interest in natural medicine is widening new interesting perspectives for this crop. Moreover, the recent success of the craft beer sector all over the world, made the cultivated hop come out from its traditional growing areas. Particularly, in Europe this resulted in a movement towards southern countries such as Italy, which added itself to the already existing hop industry in Portugal and Spain. In these relatively new environments, a complete knowledge and expertise of hop growing practices is lacking. Overall, while many studies were conducted globally on phytochemistry, bioactivity, and the genetics of hops, results from public research activity on basic hop agronomy are very few and discontinuous as well. The objective of this article is to provide an overview of possible uses, phenology, and agronomic aspects of hops, with specific reference to the difficulties and opportunities this crop is experiencing in the new growing areas, under both conventional and organic farming. The present review aims to fill a void still existing for this topic in the literature and to give directions for farmers that want to face the cultivation of such a challenging crop.

Keywords: hops; Humulus lupulus L.; Mediterranean environment; trellising system; medicinal plant; industrial crop; hop shoots; powdery mildew; downy mildew; Japanese beetle

\section{Introduction}

The common hop (Humulus lupulus L.) is a dioecious perennial climbing plant, belonging to the Cannabaceae family and native to Northern temperate climates [1,2]. Only female plants are grown, as their inflorescences (strobiles or, more commonly, cones or "hops") are rich in constituents (mainly bitter principles and essential oils) used for both industrial and medicinal purposes. Although wild hops are classified as lianose phanerophytes [3], cultivated hops are forced to behave as hemicryptophytes. In fact, when cones are ripe for harvest, climbing bines are cut at the ground level, thus stimulating the resprouting from the rootstock in the following spring.

In the last ten years, annual hop production and area harvested worldwide have increased by $34 \%$ and $18 \%$, respectively [4]. Both those indicators continuously raised 
from 2012 to 2019, achieving a total production of about 131,000 $t$ and about 66,000 ha harvested, with an average cone yield near to $2 \mathrm{t} \cdot \mathrm{ha}^{-1}$. The top producing countries are the United States of America (a little less than 51,000 t), Germany (48,500 t), and Czech Republic (7150 t). However, the European Union (EU-27) is largely the main global hop producer, accounting for almost $50 \%$ of world hop production [4].

Hop cultivation area is limited mainly by the photoperiodic needs of the plant [2]. The lowest latitudes at which a commercial production is feasible are approximately $34-35^{\circ}$ in both hemispheres and, even here, there are problems for the too short day length. Due to these considerations, including Ethiopia (which lies between the $3^{\circ} \mathrm{N}$ and $15^{\circ} \mathrm{N}$ Latitude) among the main hop producing countries [5], is an incorrect information. Moreover, for optimal growth, yield, and cone quality, hop plants need particular climatic conditions such as exposure to low temperatures during dormancy, mild temperature in spring, sufficient moisture from irrigation or rainfall throughout the season, and dry weather during harvest time $[2,6,7]$. For that reason, in Europe, hop cultivation historically developed in both continental and temperate regions, characterized by $D f b$ and $C f b$ climate (humid continental climate and oceanic climate, respectively), according to the Köppen-Geiger classification system [8]. Traditional European hop production areas are the Hallertau in Germany, the Žatec region in Czech Republic, Kent in the South East of England, the Lublin region in Eastern Poland, Savinja Valley, Ptuj, and the Koroška region in Slovenia, Alsace in France, the Poperinge area in Belgium $[9,10]$.

The global growing popularity of craft beer in the last decades [11] fostered many brewpub owners and microbrewers to grow their own local hopyard, thus making hop overstep its typical cultivation borders. In Europe, this resulted in a movement towards southern countries such as Italy, which added itself to the already existing hop industry of Portugal and Spain. In these environments, a very limited knowledge about hop growing practices exists, since hop phenology, crop requirements, and hopyard management may be very different from those known and applied in the traditional hop lands. Overall, while many studies were conducted globally on phytochemistry, bioactivity, and genetics of hops ([12], and references therein), results from public research activity on basic hop agronomy are very few and discontinuous as well $[13,14]$.

The objective of this article is to provide an overview of possible uses, phenology, and agronomic aspects of hops, with specific reference to the difficulties and opportunities this crop is experiencing in the new growing areas, under both conventional and organic farming. The review aims to fill a void still existing for this topic in the literature and to give directions for farmers that want to face the cultivation of such a challenging crop.

\section{Uses}

Even though hops are mainly known as one of the four ingredients of beer, their first use was as a medicinal plant [15]. Almost all plant parts are rich in bioactive compounds such as bitter acids, and flavonoids [16,17], having potent antimicrobial, antioxidant, and antifungal activity. These features coupled with the growing interest in natural healthpromoting substances, open new interesting perspectives for hops beyond the beer industry $[18,19]$. During centuries and until now, from hop cultivation human beings obtained several products such as tea, cordage (using stems), food (cooking the young shoots), and even a preservative for bread $[2,20,21]$. In the following sections, all ways to use hops will be reviewed, with an emphasis on their health-promoting properties.

\subsection{As Medicinal Crop}

Since ancient times, hop has been recognized as a medicinal plant [22,23]. Over centuries, hops were used as remedy for leprosy, pulmonary tuberculosis, silicosis, indigestion, ear infection, and many other complaints ([24,25], and reference therein). Starting from the 19th century, hop preparations have always been recommended as a mild sedative useful for relief of mental stress and to aid sleep [26]. The potential sedative effect of hops was first supposed observing the bizarre characteristic known as "hop-picker fatigue". It was 
noticed that hop-pickers tired easily during their job and this was attributed to inhalation of the volatile oil of the hop plant or even to the transfer of hop resin from hands to mouth during harvesting and processing of cones [27,28]. Even now, pillows filled with hops (alone or together with valerian and lavender) are sold as an efficient remedy for insomnia. Despite this and different published researches suggesting hop sedating properties [29,30], there is still insufficient evidence from clinical studies to confirm the real effectiveness of hops in the treatment of sleeplessness [25]. However, a more recent study, conducted on 17 female nurses, concluded that, thanks to its hop components, a moderate consumption of non-alcoholic beer favors night-time rest [31].

Beside sedative effect, another medicinal property of hops was discovered thanks to hop-pickers: its estrogenic activity [32]. When hops were harvested by hand, menstrual disorders frequently happened among female pickers [33]. Initially, the estrogenic activity was attributed to xanthohumol [34], until a potent phytoestrogen, 8-prenylnaringenin (8-PN), was identified in hops and beer $[33,35]$. Nowadays, supplements containing hop phytoestrogens are often used for menopausal symptoms, breast enhancement, and bone health [36-38].

In the last 25 years, many studies have been conducted to demonstrate the anticarcinogenic properties of hop secondary metabolites ([24,25,39], and reference therein). Xanthohumol was the compound mainly investigated for its properties of chemopreventive agent, but also bitter acids and essential oils proved to have an anti-cancer activity ([24,25], and reference therein).

In general, the strong antimicrobial, antioxidant, and antifungal effectiveness of hop extracts is well documented [12,15,40-42]. The bitter acids, particularly humulone and lupulone, are the main agents of the antibacterial and antifungal effects ([25], and reference therein).

Recently, treatment with iso- $\alpha$-acid extracted from hops was found to soothe or prevent different ailments such as liver steatosis, inflammation, and fibrosis as well as metabolic disorders such as obesity and diabetes ([43,44], and reference therein).

\subsection{As Industrial Crop}

The use of hops in brewing has more than a thousand years of history, since the first records on hops as a cultivated plant were dated between the 8th and 9th century A.D. $[2,45,46]$. Hop cultivation started in Central Europe (in the regions of Bohemia, Slovenia, and Bavaria) and, from there, it gradually spread across Europe and, then, in the rest of the world [2]. Currently, hop is almost entirely grown for the brewing industry [47].

Even though hop cones contain a variety of compounds, such as resins, essential oils, proteins, polyphenols, lipids, waxes, cellulose, and amino acids, the brewing value of hops is mainly attributed to hop resins and essential oils. Both these components are synthesized in the glandular trichomes (lupulin glands, Figure 1) of hops [48]. Total hop resins can be divided into soft and hard resins. Soft resins are more important than hard ones in the brewing process and consist of the $\alpha$-acids, $\beta$-acids, and the so-called uncharacterized soft resins. The $\alpha$-acids are the source of the bittering agents of beer, the iso- $\alpha$-acids, which also have a remarkable bacteriostatic activity during wort boiling. However, the dependence on pasteurization made the preservative function of the hops irrelevant in the modern and industrial brewing process.

On the basis of their chemical composition, hop varieties are simply classified as "bittering hops" or "aroma hops". Besides that, according to $\alpha$-acid content, bittering hop cultivars are classified as "bittering hops", "high alpha", and "super high alpha". Similarly, the hop oil composition distinguishes "fine aroma hops" from "aroma hops" [47]. A further distinction was proposed to define the so-called "flavor hops" [47]. This kind of hops are characterized by adding a distinct taste and intense flavor to beer, and can come either from bittering or aroma cultivars [47]. 


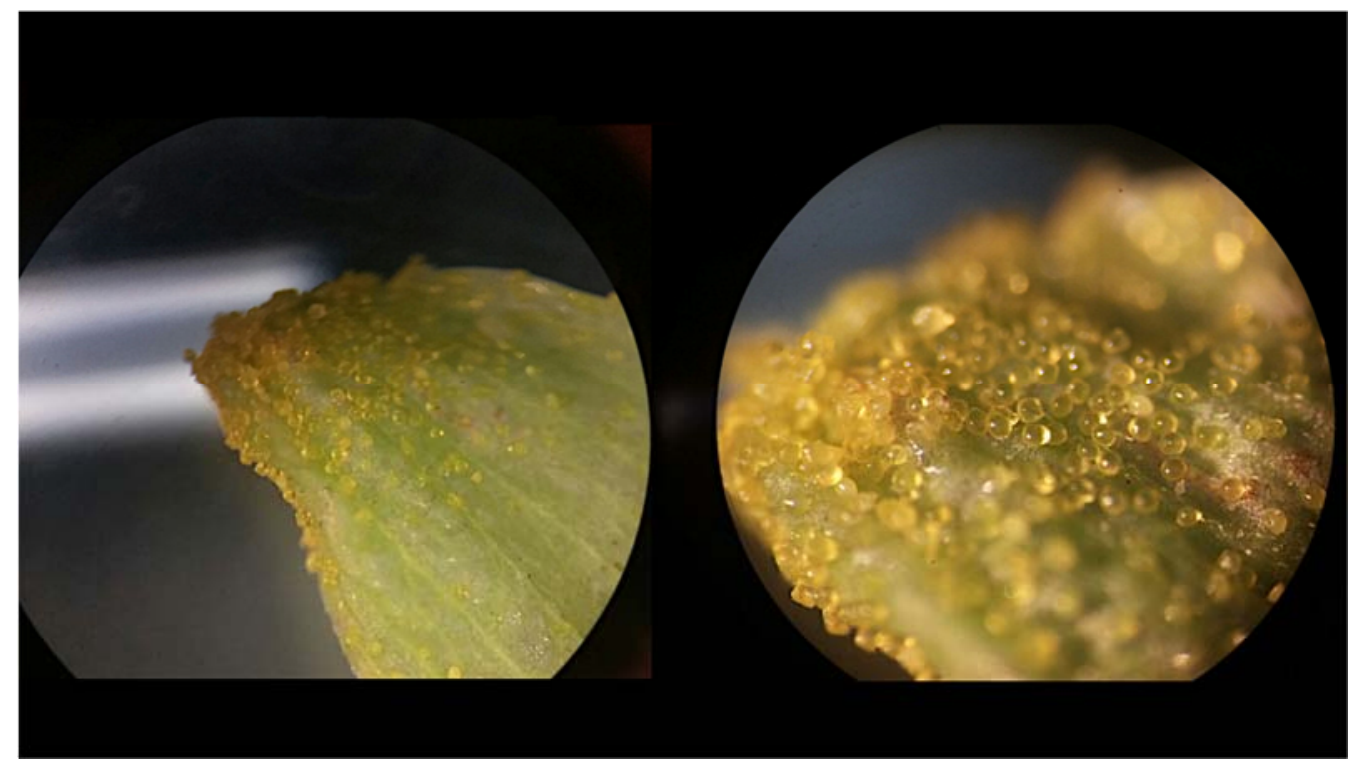

Figure 1. Glandular trichomes from female hop bracts.

For many years, the main role of hops in brewing was to give a bitter taste to the beer, and, often, hops were purchased just for this reason. This is particularly still true for many big brewing companies that are more interested in the $\alpha$-acid content than in other hops' characteristics. Conversely, current consumers' attitude shows a growing appreciation of flavor and perceived quality of beer [49,50], while less importance is given to bitterness. As a result, in the last decade, many farmers shifted their production to more aroma hops [10]. Unfortunately, many traditional aroma hop varieties are often characterized by low yields and high susceptibility to pathogens, thus making them unappealing for hop growers [51]. For this reason, much of the effort of the hop breeders is devoted to obtaining genotypes having quality traits similar to those of traditional varieties but with improved yield potential and disease resistance.

\subsection{Other Uses}

Picking and cooking the young and tender hop shoots emerging from rootstock in the spring, was probably the very first way to use hop plants. It seems that the first written document on this habit was the Naturalis Historia in which Pliny the Elder (23-79 A.D.) claims that lupum salictarium (probably, the young shoots of common hop), and other wild plants, are eaque verius oblectamenta quam cibos, namely, "more a pleasure than a food". Besides their culinary appreciation in many European regions (from Belgium to Spain, from England to Italy), young hop shoots, both wild and cultivated, have a very low fat content and were found to be a good source of dietary fiber, proteins, and vitamins C, E, and B9 [52-54]. Additionally, in a recent study carried out in Slovenia by Vidmar et al. (2019) [55], white hop shoots from different cultivars showed a better antioxidant activity than hop cones and leaves.

Since only the female inflorescences have interest in the industrial cultivation of hops, a large quantity of plant residue is left on the field after cone harvest. This leftover material consists almost exclusively of leaves and stems. Similarly to hemp (Cannabis sativa L., belonging to the same family of hops), hop stems are rich in bast fibers usable for paperand rope-making [20]. Thus, applying the principles of circular economy to the hopyard management, dead stems could be efficiently re-used as training strings supporting living stems. However, it is worth mentioning that the retting process of the long, twisted stems of hops is difficult compared to straight stems of flax, hemp, and nettle [20].

Besides the pharmaceutical application, the well-known antimicrobial and antifungal activity of many hop compounds was exploited also for the biocontrol of pests and plant diseases. Specifically, bitter acids and essential oils were found to be effective control agents 
or repellants against the invasive mosquito Aedes albopictus (Skuse) (Diptera Culicidae) and fresh water snail Physella acuta (Draparnaud) (Mollusca Physidae) [56], insect pests of stored foods [57], the honeybee mite Varroa destructor (Anderson and Truman) [58], and the ascomycete fungus Zymoseptoria tritici (Desm.) Quaedvlieg \& Crous [15].

Moreover, the efficiency of hop extracts as a natural food preservative was demonstrated for meat, cheese, and bread, thus meeting the increasing demand for products without additional chemicals $[21,59,60]$.

\section{Hops in the Mediterranean Basin}

Even though hops belong to the spontaneous flora of many European countries surrounding the Mediterranean Basin, its cultivation never widespread significantly in that region. The reasons can be found in the following social, historical, and environmental aspects: (i) lower beer consumption as compared to central and northern Europe; (ii) strong competition with grape and political power of wine producers over the history; (iii) high irrigation requirement during crop cycle in a region well known for its water shortage issues.

\subsection{Phenology}

Hop phenology is divided into nine principal growth stages (Figure 2): (0) sprouting; (1) leaf development; (2) formation of side shoots; (3) elongation of bines; (5) inflorescence emergence; (6) flowering; (7) development of cones; (8) maturity of cones; (9) senescence and entry into dormancy [61]. A specific heat sum, expressed as growing degree days (GDD), is required for the completion of each phenophase in different crops and varieties. For this reason, studying hop phenology in new growing areas (e.g., southern European environments) can give useful directions for both selection of cultivars and temporal optimization of agronomic practices. To the best of our knowledge, just two studies, both in Italy, described the phenology of hops in the Mediterranean Basin [14,62]. Specifically, Rossini et al. (2016) [14], in a three-year open field study, calculated the GDD accumulation for the onset of each of the four key growing stages (sprouting, flowering, development of cones and maturity of cones) of twenty hop cultivars in Central Italy. They found that 'Cascade', 'Phoenix', and 'Yeoman' were always the earliest cultivars in each phenological stage, while 'Perle', 'EKG', and 'H. Spat' were the latest ones. Marceddu et al. (2020) [62], in their two-year pot experiment, showed the progress of development stages for three hop varieties in the semi-arid environment of Sicily. They calculated GDD accumulation starting from transplanting date in which plants were at the second pair of leaves unfolded (phase 1.2, according to $\mathrm{BBCH}$ scale, [61]). They found the hop growing cycle varying from 108 days for 'Chinook' in 2019 to 147 days for 'Nugget' in 2018. The duration of vegetative stages prevailed, in almost all cases, on that of reproductive ones. However, this study did not consider the first hop phenophase: the break of rootstock dormancy and the emergence of shoots from the soil. Conversely, this stage was accurately monitored by Ruggeri et al. (2018) [63] for nine commercial cultivars in a two-year open field study in Central Italy. The authors found that some cultivars such as 'Cascade', 'H. Magnum' and 'Yeoman' were consistently recorded as the earliest sprouting varieties, while 'Perle', 'H. Bitter', and 'Tettnager' as the latest ones. Conversely, 'Fuggle' showed the highest variability between the two years for the breaking of dormancy (79 GDD vs 301 GDD). The difference between the earliest and latest cultivar ('Cascade' and 'Perle', respectively) was about 111 GDD (20 days) in 2013 and 208 GDD (31 days) in 2014. The high variability in shoot emergence date between years led the authors to conclude that further studies should be conducted to find the model that best predicts the break of dormancy. Overall, recording the date of shoot emergence (growth stage 09) in Central Italy $\left(42^{\circ} 26^{\prime} \mathrm{N}, 12^{\circ} 04^{\prime} \mathrm{E}\right.$, altitude $310 \mathrm{~m}$ a.s.l.) over five years, we observed the majority of cultivars emerging from the soil between the last decade of March and the first decade of April (Table 1).

Since hop is a short-day plant, the transition between vegetative and reproductive growth happens when day length drops below the critical threshold of 15-16 h [2,64]. 
The timing of flowering can significantly affect cone yield, because a complete vegetative growth (about 5-6 m height) prior to flower differentiation is pivotal to obtain high yields. Day length depends on latitude, and latitude varies approximately from $36^{\circ}$ and $45^{\circ} \mathrm{N}$ in the Mediterranean regions of Europe. In that range, the longest day length of the year varies from $15 \mathrm{~h}$ to $16 \mathrm{~h}$, thus allowing hop plants to reach an adequate vegetative growth before flowering. Observing the phenology of hops in Central Italy $\left(42^{\circ} 26^{\prime} \mathrm{N}, 12^{\circ} 04^{\prime} \mathrm{E}\right.$, altitude $310 \mathrm{~m}$ a.s.l.) for many years and cultivars, we recorded flowering phase approximately from mid-June to mid-July; development of cones, from the end of June to the end of July; cones ripe for picking, from the last decade of August to the last decade of September.

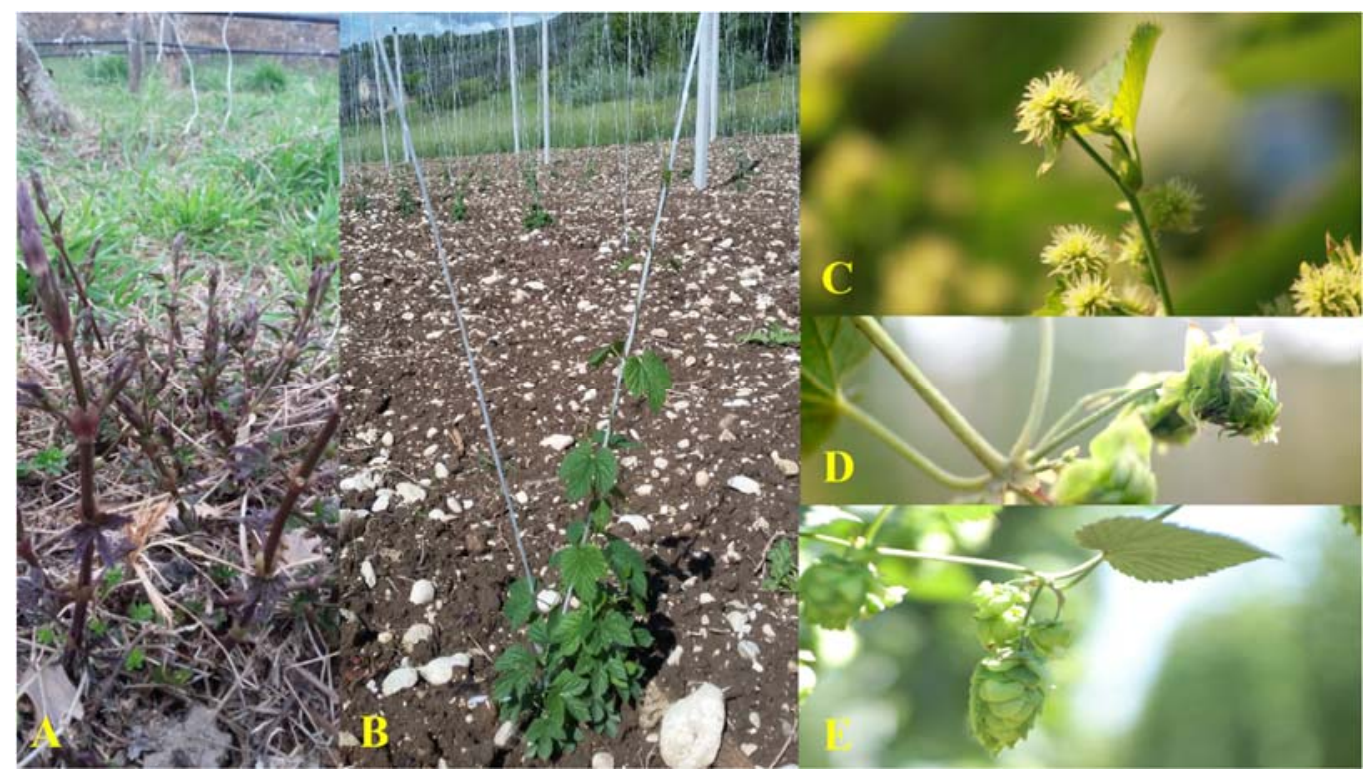

Figure 2. Some phenological growth stages of hop: (A) shoot emergence; (B) leaf development; (C) flowering; (D) development of cones; (E) maturity of cones.

Table 1. Dates of shoot emergence recorded over five years for different hop commercial cultivars in Central Italy.

\begin{tabular}{|c|c|c|c|c|c|}
\hline Cultivar & 2013 & 2014 & 2015 & 2017 & 2018 \\
\hline Cascade & 25 March & 28 March & 19 March & 18 March & 27 March \\
\hline Challenger & 22 March & 2 April & 31 March & 16 March & 26 March \\
\hline Columbus & 22 March & $28 \mathrm{March}$ & 19 March & 21 March & 26 March \\
\hline Fuggle & 29 March & 18 April & 30 March & 4 April & $30 \mathrm{March}$ \\
\hline H. Aroma & 8 April & 14 April & 27 March & 22 March & 26 March \\
\hline H. Bitter & 12 April & 23 April & 30 March & 18 March & $30 \mathrm{March}$ \\
\hline H. Magnum & 29 March & 31 March & 23 March & 18 March & 26 March \\
\hline H. Mittlefruh & 6 April & 10 April & 23 March & 16 March & 29 March \\
\hline HNB & 15 April & 23 April & 31 March & 28 March & $28 \mathrm{March}$ \\
\hline H. Spat & 6 April & 23 April & 31 March & 24 March & 30 March \\
\hline H. Taurus & 3 April & 10 April & 2 April & 4 April & 29 March \\
\hline H. Tradition & 3 April & 24 April & 31 March & 4 April & 26 March \\
\hline Omega & 8 April & 14 April & 27 March & 22 March & 27 March \\
\hline Perle & 15 April & 29 April & 31 March & 29 March & 6 April \\
\hline
\end{tabular}

\subsection{Cultivation}

Although many amateur hop growers consider hops as an easy-to-grow plant, managing a commercial-scale hopyard is markedly more challenging. Professional hop cultivation requires a well-designed structure, well-timed pruning, careful bine training, and the proper application of all the other agronomic practices to succeed in obtaining high yields and production quality. 


\subsubsection{Trellising System}

Commercial hop production requires a trellising system to support plants. The conventional high trellising system consists of a permanent structure of poles and wire to which strings are attached each year to provide support for the hop bines [2]. Poles can be made of treated wood, iron, steel, or concrete. Pre-stressed concrete poles are much more expensive than wood ones, but they better withstand mechanical stress. Growers should be informed that the trellis is an engineered structure subject to heavy loads, including the plant (heavier when wet) and wind. The top height of such structures can vary, but usually ranges from $5 \mathrm{~m}$ to $8 \mathrm{~m}$. The most common training system used for hop production worldwide is the V-trellis (Figure 3), and the same is also used in the Mediterranean region [14,65].

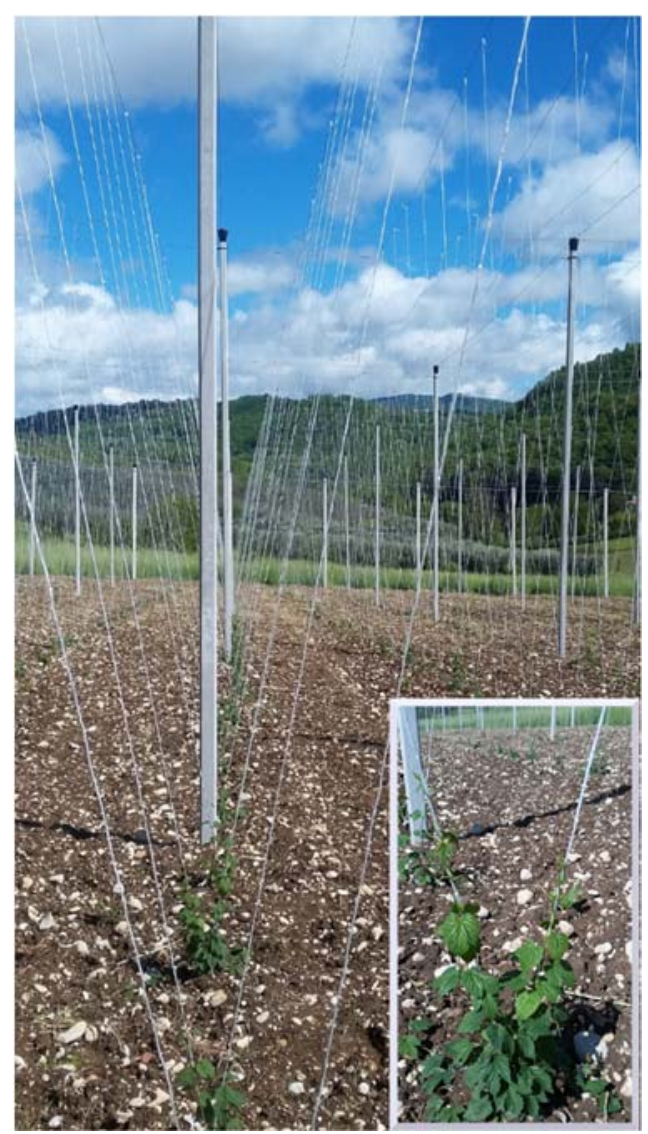

Figure 3. V-trellis system.

Since the standard high trellising system is very expensive and labor-intensive, alternative solutions have been searched over years. Low trellis is probably the most famous growing system proposed as a substitute of the typical high trellis. Overall, the low trellising system consists in growing hops on netting fastened to $3 / 4 \mathrm{~m}$ tall poles.

Generally, hops growing on low trellis yield less compared to those thriving on high trellis [66]. However, the benefits related to plant health (easier and more effective control of pests and diseases, [67]), harvest efficiency, worker safety, and cost for construction and maintenance, make low trellis very interesting for small-scale producers and worthy of deeper investigations in different environments and with suitable cultivars (e.g., dwarf or low-cone setting genotypes). Currently, no studies comparing low and high trellising systems, under Mediterranean climatic conditions, have been published. Additionally, our experience suggests that, probably, the most used $6 \mathrm{~m}$ high trellis is not the best system to train the hops under climatic conditions of Italian peninsula. In fact, we observed many hop bines grow taller than the top wire and develop horizontally more than required. 
This behavior creates serious problems during harvest for bine intertwining and during cultivation for plant shading.

\subsubsection{Cultivars and Propagation}

According to the International Hop Growers' Convention (IHGC), commercial hop varieties produced in 2020 by 21 member countries were 291 (excluding experimental selections and no-named records): 69 labelled as bitter hops and 222 as aroma hops [68]. The most cultivated hop varieties in the top producing countries are 'Citra ${ }^{\circledR} \mathrm{HBC} 394$ ', 'Mosaic ${ }^{\circledR}$ HBC 369', 'Perle', 'Hall. Tradition', and 'Saaz' for aroma hops and 'Herkules', 'Hall. Magnum', 'Pahto ${ }^{\circledR}$ HBC 682', and 'CTZ' (stands for 'Columbus', 'Tomahawk', and 'Zeus') for bitter hops. As for the Mediterranean Basin, 'Nugget' is largely the predominant cultivar in Spain ( $90 \%$ of the total harvested area), and probably in Portugal too. In Italy, there are no published statistics but, presumably, 'Cascade' is the most planted cultivar for both its good adaptability to a wide range of pedoclimatic conditions and its common use in many brewing recipes. Other varieties that performed well under different experimental conditions were 'Hall. Magnum', 'Chinook', and 'Yeoman' $[14,62,63]$. Understandably, the agronomic data available from open field trials in such a new growing country are very few and collected on a limited number of plants (from three to five per replicate). Thus, there is an urgent need for more reliable data collected from commercial hopyards and in different environmental conditions. At the same time, screening of germplasm from wild hop populations is gaining interest for breeding programs having as main target the creation of different local varieties [69,70].

Vegetative propagation is the common way to multiply hops because it is both a quite simple method and a fast tool to obtain a clone of the mother plant. For these reasons, seeds are used just in breeding programs for the improvement of genetic variability. Rhizomes collected from mature rootstocks and one-node green cuttings from stems are the most commonly used materials for propagation (Figure 4). Rhizome cuttings can be planted directly into the soil or potted and then transplanted from 6 to 12 months later. While the limited availability of suitable rhizomes hampers the adoption of this method, the use of green cuttings allows a faster and more effective multiplication of hop plants.

Tissue culture is another tool to obtain large amounts of clonal plants in a short period [71]. Micropropagation was used in hops mainly for virus eradication [72], cryopreservation [73], and mass shoot production [74]. Very recently, trials conducted in Southern Italy evidenced that micropropagation protocol adopted for hops, although successful for many other crops, did not perfectly succeed in obtaining healthy and vigorous plants [62].

\subsubsection{Soil Preparation and Planting Techniques}

Although hops can thrive on a wide range of soils, those loose and well drained have to be preferred when an adequate water supply and manuring is provided [2]. Lighttextured soils also facilitate cultivation and management operations in the hopyard during both winter and summertime. Hops can grow well also in clay soils but raised beds have to be realized and an accurate surface and subsurface drainage system has to be designed prior to planting hills [65]. In fact, while hops naturally thrive along riverside and moist riparian zones, they do not tolerate waterlogged soils. Even though the majority of nutrientcollecting roots develop in the top $0-30 \mathrm{~cm}$ of soils, the root system of hops extends far down over the years (from $1 \mathrm{~m}$ up to $2.25 \mathrm{~m}$, [75]) and, thus, takes advantage from deep soils. Plowing and amending soil is a common practice before planting a new hopyard. Deep cultivation, or ripping, is suggested on compacted soils, as this will improve drainage and root penetration. 


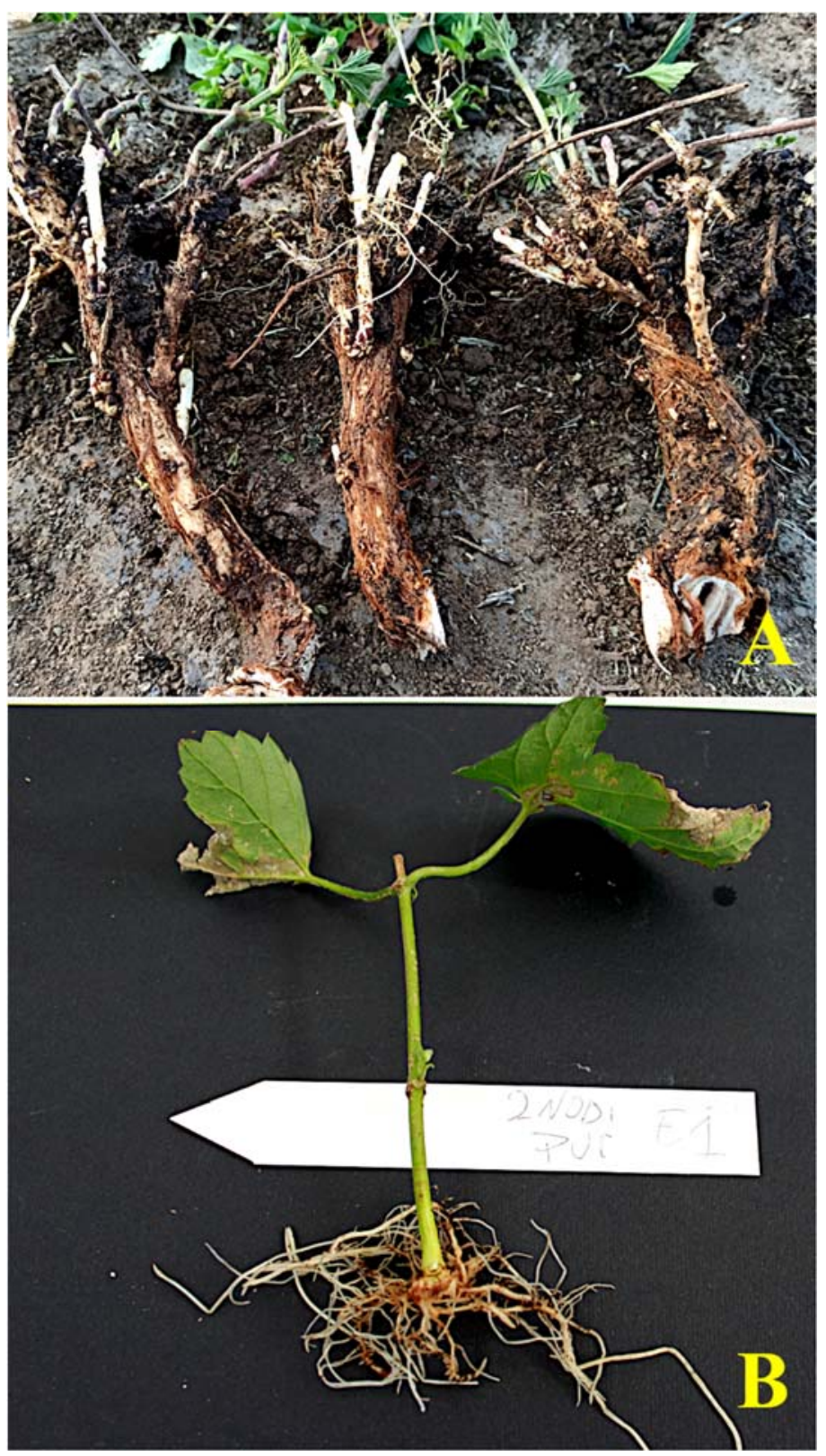

Figure 4. Vegetative propagation of hops: (A) rhizomes; (B) rooted cutting.

Potted plants are transplanted on the top of raised beds in spring or autumn, following different planting designs. Generally, plant spacing varies according to cultivar (plant vigor and cone setting), trellising system, location and available machinery [76,77]. The most used planting designs in hop producing countries consist of $2.5 \mathrm{~m}$ to $4 \mathrm{~m}$ row spacing and from 1 to $2 \mathrm{~m}$ plant spacing, accounting for 1700 to 4000 plants per hectare. Even though, plant spacing is one of the most important agro-technical issues in designing a hopyard [76], very few studies have been conducted on this aspect so far and, to the best of our knowledge, no one in the Mediterranean Basin.

\subsubsection{Pruning, Training, and Stripping}

Pruning is the spring removal of the upper part of rootstock, also known as "crown" (Figure 5). Generally, pruning is the first spring agrotechnical operation, aiming to remove shoots and crown buds. While multiple ways of mechanical and chemical pruning exist, the reasons to apply this agronomic practice are essentially two: (i) to reduce downy and powdery mildew inoculum [78] and (ii) to promote a more uniform regrowth from 
rootstock [63,77]. It was suggested that, depending on timing and severity of pruning, growers could eliminate one fungicide application per year [78]. Specifically, a fourweek delayed pruning can significantly reduce powdery mildew incidence on leaves and cones [79]. Moreover, combining the mechanical and chemical intervention generally leads to a more thorough effect compared with the application of a single method [78,79]. In new growing areas, no herbicide is currently registered for this purpose, as such, mechanical pruning is the only option available.



Figure 5. Hop pruning: (A) not pruned rootstock; (B) pruned rootstock.

Once secondary shoots regrow from "crowned" rootstock and reach the height of $50-60 \mathrm{~cm}$, it is time to train them. Training means wrapping hop bines in a clockwise direction around each string to promote vertical growth. As a rule, from two to four bines are trained up each of the supporting strings, as this results in the optimal growth for high yield and good quality [2]. Established rootstocks produce much more shoots than are needed [63] and, after training is completed, it is necessary to remove the exceeding. Surplus shoots can be collected and sold as vegetables, like asparagus spears (see Section 2.3). Indeed, leaving the excess shoots at the base of the plants would favor the development of mildew diseases and would weaken the vertical growth of trained bines.

Choosing the appropriate training date is pivotal for obtaining maximum hop yields. Moving away from the optimal date, production could be reduced by nearly $40 \%$ [80]. Understandably, the training date depends on the pruning date, with training occurring about 3-4 weeks later. While in traditional hop producing zones, the long experience with this crop led to the acquisition of a practical "know-when", pruning and training in new growing areas are mostly driven by growers' invention.

Leaf stripping (removing lower leaves and laterals) is another common management practice applied during the vegetative phase of hops. The aim is to increase air flow in the basal part of the plant, thus limiting the spread of downy mildew. Mechanical stripping 
can start when bines are at least $3 \mathrm{~m}$ high, while chemical defoliation is usually done when bines reach the top wire [2]. In the new growing areas, such as Italy, because of the absence of registered herbicides and thanks to the limited dimensions of the existing hopyards, stripping is carried out by manually removing the lower leaves up to $0.90-1 \mathrm{~m}$ from the ground. Very interesting is the way of stripping hopyards in New Zealand, the top producer of organic hops. In this country, sheep are often used to graze the hop gardens with the following benefits: direct control of weed flora, sucker pruning, lower bine defoliation and manure supply. Hopefully, this strategy could be exported in those areas of the Mediterranean Basin where growers are interested in organic hop production and a sheep farming system already exists.

\subsubsection{Irrigation and Fertilization}

Under Mediterranean climatic conditions, irrigation is unavoidable to have a marketable hop production. In Southern European environments, severe drought and heat often occur when hops are in phenological phases particularly sensitive to such stresses, i.e., flowering, cone formation and early ripening. Cone yield was found to significantly increase with crop transpiration $\left(\mathrm{r}^{2}=0.92\right)$ in Spain, with hop transpiration representing $92 \%$ of actual evapotranspiration during the mid-season [81]. In the same study, yield obtained in the rainfed plots was 37\% lower than in the irrigated ones. The picture of hops as water intensive crop clashes with water scarcity that typically afflicts Mediterranean countries. Despite this, limited studies were conducted to investigate (i) the effect of deficit irrigation on hop yield and quality, (ii) the drought tolerance in hop cultivars, and (iii) the management of irrigation systems [82,83]. Deep knowledge on these aspects will be crucial for successful hop cultivation in a global climate change scenario $[7,84]$.

The most used irrigation systems in the Mediterranean hopyards are (i) surface irrigation system by flooding the space between rows [65] and (ii) drip irrigation along rows $[14,63,81]$. The latter system is more expensive than the former one but it is more water efficient. Moreover, a drip irrigation system can allow targeted application of soluble or liquid fertilizers by fertigation and reduces the incidence of fungal diseases. Recently, Nakawuka et al., 2017 [82], reported that the use of a subsurface drip irrigation system can substantially reduce water use in hop production even before deficit irrigation is considered.

Hops do not thrive under acidic soil conditions and liming should be carried out when necessary to prevent the $\mathrm{pH}$ from falling below 6.5 [2]. Additionally, extreme $\mathrm{pH}$ values alter the absorption of many micronutrients. For example, when $\mathrm{pH}$ is acid, manganese (Mn) levels can become toxic in hop tissues [65], while zinc ( $\mathrm{Zn}$ ) deficiencies are often associated with alcaline soils (above 7.5, [6]).

Hop nutrient requirements vary depending on soil testing, cultivars, yield potential, and growing region. Nutrient application guidelines have yet to be developed for hop production in new growing zones. Thus, indications published in other countries currently are the best available reference. As for nitrogen (N), $160 \mathrm{~kg} \cdot \mathrm{ha}^{-1}$ (split in two applications) were recommended in Slovenia [85], $168 \mathrm{~kg} \cdot \mathrm{ha}^{-1}$ in the USA [86], and $135 \mathrm{~kg} \cdot \mathrm{ha}^{-1}$ in England [2]. In the Mediterranean basin, Afonso et al. (2020) [65] reported $150 \mathrm{~kg} \cdot \mathrm{ha}^{-1}$ of $\mathrm{N}$ (split in three applications) in Portugal, while $100 \mathrm{~kg} \cdot \mathrm{ha}^{-1}$ of $\mathrm{N}$ (split in two applications) was used in Italy [14].

The need for phosphorus (P) fertilization is often overestimated. Hops typically have low $P$ requirements, with suggested $P$ amount to be applied ranging from 67 to $110 \mathrm{~kg} \cdot \mathrm{ha}^{-1}$, when soil P concentration into the soil is very low (0-30 ppm, [87]).

Hops take up $90-170 \mathrm{~kg} \cdot \mathrm{ha}^{-1}$ of potash $(\mathrm{K})$, but $75 \%$ can return to the soil with vegetative plant parts [87]. With high soil contents or heavy applications of farmyard manure, no additional phosphate or potash is generally considered necessary [2].

With the increasing interest towards organic hops, alternative ways to improve soil fertility have been proposed such as the use of leguminous cover crops, compost, slurry, farmyard manure, and other soil amendments [2,6,88]. However, meeting crop 
nutrient demands (especially for $\mathrm{N}$ ) remains a challenging task when using organic fertilization $[89,90]$.

Fertilizer placement is also important when considering plant nutrient needs. Broadcasting fertilizer makes the nutrients more available for weeds and can encourage their growth and competition with crops [91]. Thus, the best way to feed hop plants is the localized applications of fertilizers or, even better, the use of fertigation systems. Brant et al. (2020) [75], studying the distribution of root system in hop plants, suggested to place the fertilizers at $50 \mathrm{~cm}$ far from the center of the rootstock in both sides.

Besides having an annual soil testing report, tissue analysis is a recommended method to determine plant nutrient needs and detect potential deficiencies [92]. Hop petioles from mature leaves should be collected during growing season and analyzed for macro- and micronutrient content. If results show deficiencies, foliar fertilization or fertigation must be applied to restore a correct plant nutrition.

Finally, it is worth mentioning that, despite the growing interest towards the application of plant biostimulants in other crops, studies conducted on this topic are very few for hops and no one in the Mediterranean Basin. In a recent study, Prochazka et al. (2018) [93] found that complex formulations of biologically active substances, such as fulvic and humic acids and phytohormones, appear to be highly effective for the optimization of hop production performance in Czech Republic.

\subsubsection{Disease, Pest, and Weed Control}

Our ten-year experience in hopyard management, under the Mediterranean climatic conditions of Italy, underscored that mildew pathogens, aphids, and spider mites were the constant and most problematic diseases and pests that can really compromise the hop production. It should be noted that in Northern Italy, where maize is largely cultivated, another pest that can damage hops is the corn borer (Ostrinia nubilalis Hübner). The restricted availability of plant protection products registered for hops severely limits the strategies for pest and disease control in both organic and conventional farming. Thus, hop protection management must focus on the proper agronomic practices, preventive intervention and biostimulants for induction of plant resistance [93]. These products determine a higher resistance of plant tissues (e.g., vaterite) and a higher synthesis of phytoalexins. Additionally, they are not dangerous for health and do not leave toxic residues into the soil.Hereafter, the main diseases and pests detected in our surveys will be shortly described. Lastly, some thoughts about weed control strategies in hopyard will be briefly discussed.

Downy mildew Caused by Pseudoperonospora humuli (Miyabe \& Takah.) G. W. Wilson

Downy mildew can overwinter in infected hop rootstocks in the form of mycelium ([2], and references therein). Contaminated buds originate primary infected shoots (known as "basal spikes" due to their resemblance to a wheat spike) with a characteristic stunted form and pale down curled leaves [2,78]. These spikes are the primary source of infection each year. In our experience, this first infection can be limited by pruning. Infections of buds and leaves can develop at any time during the growing season, depending markedly upon weather conditions and the amount of inoculum being released [2]. This secondary infection can be controlled with copper-based products, when the hops flower, the developing burr, and cones may also become infected. Diseased cones turn brown and tend to break with mechanical harvesting.

Powdery mildew Caused by Podosphaera macularis (Wallr.) U. Braun \& S. Takam.

Disease symptoms appear as powdery white colonies on leaves, buds, stems, and cones. Raised blisters can be visible when plant grows rapidly. In the same way of downy mildew, primary infection starts from diseased shoots (termed as "flag shoots") and then the pathogen spreads on young leaves, moving up the bine in sync with plant growth $[78,79]$. Disease development is favored by rapid plant growth, mild temperatures, 
high humidity, and cloudy weather [2]. Burrs and young cones are very susceptible. We have never recorded severe attacks of powdery mildew in Italy. However, where infections have been detected, sulfur-based products have well controlled the pathogen. It should be noted that recently, in Italy, orange oil-based products have been registered for the control of powdery mildew in hops, but we have not had any experience about their effectiveness.

\section{Spider Mite (Tetranychus urticae C.L. Koch)}

Together with aphids, spider mite (also known as two-spotted mite) is the key pest of hops in the Northern hemisphere [2]. In small numbers, the mites do not cause much damage but, under favorable conditions, they can multiply very rapidly and become a serious problem [2]. Since spider mites thrive in hot and dry environments, it is clear that it could represent a serious problem under Mediterranean climatic conditions. Personal observations on open-field trials suggested that Beauveria bassiana-based products and mineral white oil-based products were effective in controlling these pests. Ground cover mixes have been shown to host mite predators, thus regulating their presence [67].

\section{Damson-hop aphid (Phorodon humuli Schrank)}

This pest usually causes both direct damage, by feeding sap and debilitating the plants and an even worse indirect damage, by transmitting viruses. The main problem arises after cone formation, because sooty molds easily develop on the honeydew produced by the aphids, thus compromising the quality and commercial value of the hops [2] Personal observations on open-field trials suggested that pyrethrum-based products and Beauveria bassiana-based products were effective in controlling these pests. Enhancing habitat to favor the presence of beneficial predators gave contrasting results in the reduction of aphid population [67].

The biotic stresses described until now are managed, both organically and conventionally, in all countries where hops are traditionally grown. In these countries, different options are available for hop growers to protect their crops. Understandably, in new growing countries such as Italy, products registered for use on hops are very few. In 2020, copper-based and sulfur-based products were temporarily allowed as an exception for the control of fungal diseases. A Bacillus thuringensis-based product was also registered for use on hops against the corn borer. Currently, there is nothing else as authorized product for hop protection.

\section{Viroids}

Even though we did not survey any stunted hop plant infected with viroids in our field trials, we touch this topic because viroids represent serious damaging pathogens in the neighboring hop producing countries such as Slovenia [94]. Hop latent viroid (HLVd) is the most diffuse viroid of hops and has been recently detected in many commercial cultivars sampled along the Italian peninsula [95]. Hop stunt viroid (HSVd), Apple fruit crinkle viroid (AFCVd), and Citrus bark cracking viroid $(\mathrm{CBCVd})$ are the other viroids infecting hop plants around the world [96]. Among them, CBCVd seems to be the most aggressive type, causing yellowing, leaf malformation, bine cracking, and plant stunting after a post-inoculation period of only 14-months [94,97]. Since infected plants often show no visible symptoms (e.g., plants infected by HLVd), the vegetative propagation of hops easily diffuses the pathogens. The use of virus/viroid-free planting material is the most effective and obvious strategy to limit the spread of this plant disease.

Japanese beetle (Popillia japonica Newman)

Popillia japonica Newman (Coleoptera: Rutelidae) is a scarab beetle native to Japan and established in North America, the Azores and, more recently, in Northern Italy [98]. Japanese beetle is a highly polyphagous species that is listed in Annex IAII of the Directive 2000/29/EC. In our experience, we have been able to observe the damage caused by this pest in a hopyard located near Milan (Northern Italy). The presence of adults on hop 
plants was recorded in the period July-August 2019, and it was deleterious (Figure 6). Japanese beetle fed on the hop leaves, significantly reducing the photosynthetic activity of the plants. It seemed they were not interested in feeding on the flowers, but this was only an observation. Since the Japanese beetle is an alien species for our territory, the control of this pest is rather complicated. Solutions could involve agronomic practices applied to the meadows where the larvae overwinter, and the registration of pesticides (for organic and conventional farming) before this insect becomes a real emergency.

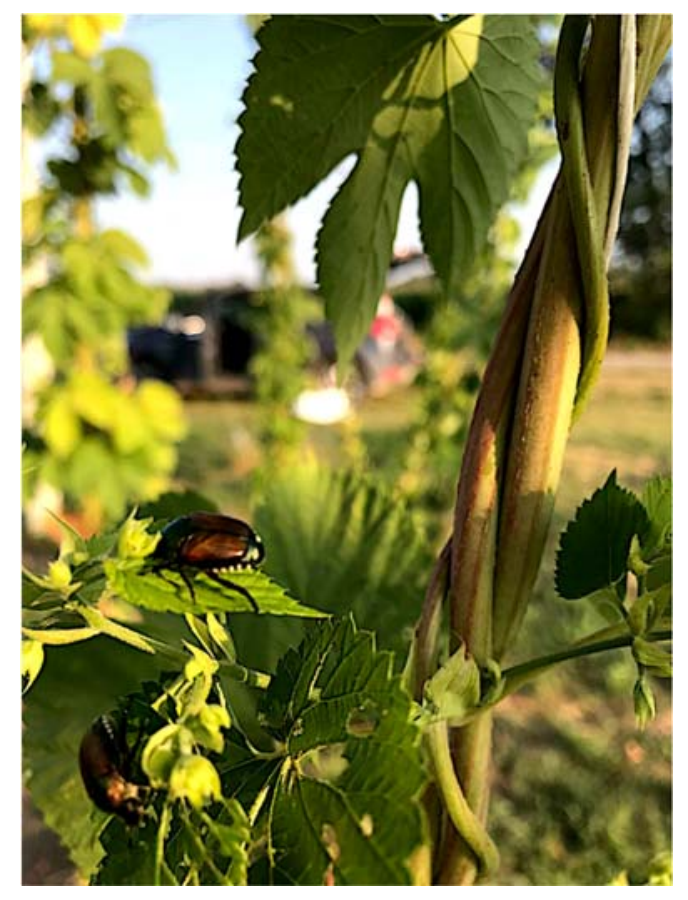

Figure 6. Japanese beetles (Popillia japonica Newman) feeding on hops.

\section{Weed Control}

Hop demand for nutrients and water is very high in the period of intensive growth, and weeds can greatly compete for these resources [99]. Obviously, competition for light is temporarily limited to the phenological phase of shoot emergence. Thus, weed management in dormant-early spring season is necessary to maintain a weed-free strip along the rootstocks [77]. Moreover, weed presence can interfere with some field operations such as spraying, training, and harvesting, thus reducing both the efficacy and efficiency of these agronomic practices. Mechanical cultivation, chemical control, and mulching are the most common ways to control weeds in hop production $[6,13]$. Generally, in conventionally managed hopyards, weed control involves mechanical tillage between rows and in-rows herbicide applications [99]. Conversely, organic hop growers rely mostly on a combination of tillage practices, the use of cover crops, mulching, and grazing sheeps $[13,100]$. We hypothesize that, in small-scale Mediterranean hopyards, scratching poultry also might be effective. Cover-cropping the inter-rows may be a useful way to control weeds in organic hopyards as well as to attract beneficial insects and enable machinery to drive in the field sooner after precipitations [13]. Ideal cover-crop species should be native, with low requirements and low competitive ability. Studies targeted to identify cover crops suitable for hopyard management in the Mediterranean environment are lacking [101].

Paradoxically, in new growing areas, such as Italy, where registered herbicides for use on hops does not exist yet, conventional and organic weed management coincide. Identifying the weed species and their life cycles are the crucial aspects for a successful weed management plan. In our experience, the most common and problematic hop weeds in Italy are the summer annuals like Amaranthus retroflexus L., Solanum nigrum L., 
Chenopodium album L., and the perennials such as Cynodon dactylon (L.) Pers., Sorghum halepense (L.) Pers., Calystegia sepium (L.) R. Br., and Convolvulus arvensis L.

Findings on weed management in the Mediterranean hopyards were not published so far.

\subsubsection{Harvesting, Yield, and Post-Harvest Processing}

Mature cones must be harvested, cleaned, and dried in the shortest time possible, to ensure optimum quality and storability. Depending on maturity timelines of cultivars, a typical hop harvest period can be approximately one month [77]. In Southern European environments, hop maturity generally occurs during the months of August and September $[63,65]$.

The hop harvest takes place in two phases: cutting of the whole plant in the field (harvesting) and the separation of the cones from the bines (picking). For both operations, different types of machinery are used.

The global average yield for hops was $2.12 \mathrm{t} \cdot \mathrm{ha}^{-1}$ in 2019, with some national yield reported in Table 2 [68]. Other yield reports for Southern Europe come from the very few open field studies conducted in Italy and Portugal $[14,63,65]$. In Italy, cone yield largely varied with cultivar and plant age, from about $30 \mathrm{~g}$ to $700 \mathrm{~g}$ per plant [63], while in Portugal, cultivar Nugget yielded from $75 \mathrm{~g}$ to $1193 \mathrm{~g}$ per plant [65]. However, it must be noticed that, in these first experimental studies, few plants were sampled per plot (from 3 to 6). Further studies with increased plot dimensions are needed to have a more realistic quantification of hop yield potential [85].

Moisture content of freshly harvested hops must be lowered from nearly $80 \%$ to $8-12 \%$, to ensure optimum quality and storability [2]. There are different types of ovens used in the various traditional cultivation areas: tower, tunnel or trench. All systems are based on the circulation of hot and dry air (which can be conveyed to the hops mass from above or below) and on the extraction of cold and humid air. The air can be heated with different methods (gas, coal, petroleum derivatives, electricity, or solar). Generally, the process should not exceed 10-12 $\mathrm{h}$ with a maximum temperature of the hops mass of $45-50{ }^{\circ} \mathrm{C}$.

Table 2. Average cone yield for some hop producing countries in 2019.

\begin{tabular}{cc}
\hline Country & 2019 Hop Yield (t.ha $\left.\mathbf{H}^{-\mathbf{1}}\right)$ \\
\hline Czech Republic & 1.43 \\
Germany & 2.40 \\
Poland & 2.14 \\
Slovenia & 1.61 \\
Spain & 1.61 \\
UK-England & 1.77 \\
USA & 2.15 \\
\hline
\end{tabular}

Finally, the dried hops need to be packed in food-grade plastic bags by means of presses dedicated to packaging hops. These bales can have a weight of $40-50 \mathrm{~kg}$ and it is good to store them in a cold room at $4-5{ }^{\circ} \mathrm{C}$ to avoid oxidation of the mass and the deterioration of the product.

All these machinery and processing systems have industrial dimensions, not economically sustainable for the small-scale production. For these reasons, most of the small Italian farms and companies have resorted to (i) the purchase of used machinery from Central European markets or (ii) the creation of smaller prototypes suitable for the small-scale production. Both solutions have pros and cons. Used machines are very cheap, they offer a certain reliability, even if, in most cases they are more than thirty years old. Conversely, they have the serious issue of not meeting with workplace safety standards. The second approach allows to obtain high-performance machines for the small-scale production (i.e., small, easily transportable, and multifunctional machines), fully compliant with safety 
regulations, but very expensive. This can only be justified for farms that do not only produce hops but also make beer and sold it directly on the market.

A separate discussion is warranted for the last post-harvest operation: the pelletization. To minimize deterioration, many brewers either keep their hops in cold store or have them processed into pellets [2]. A process that retains most of the character of the hop cones is to grind them to a powder, which is then compressed into pellets. Packing the pellets in vacuum or inert gas ensures they have a long shelf life with limited losses in brewing value [2]. Hop cones have a density varying between $130 \mathrm{~kg} \cdot \mathrm{m}^{-3}$ and $150 \mathrm{~kg} \cdot \mathrm{m}^{-3}$. The greater density of pellets, around $500 \mathrm{~kg} \cdot \mathrm{m}^{-3}$, reduces the transport volume and enables long storage stability through quality-preservation packing in a protective atmosphere. The pellets, known commercially as type 90 pellets, obtain their name from the ratio of approx. $90 \mathrm{~kg}$ of pellets obtained from $100 \mathrm{~kg}$ of hops. The lupulin-enriched hop pellets, also known as type 45 pellets, are obtained through mechanical enrichment of the lupulin gland when the hop is frozen $\left(-35^{\circ} \mathrm{C}\right)$ [102].

The Italian market almost exclusively requires pelleted hops. In fact, modern microand industrial breweries are designed for the use of hop pellets. It is therefore evident that the Italian hop producers are equipping themselves to supply pelleted hops to national brewers. To obtain pellets from their hop cones, Italian producers send their hop cones to foreign pelletization centers or, with small machinery, pelletize directly in their farms.

While pellet has innumerable advantages in terms of storage space and shelf life, using hop cones can provide beer with a panorama of wider and more intense taste descriptors [14]. We recently verified that, with a relatively simple modification to the production systems, also the hop cones could be safely used in the homebrewing process.

The Italian hop supply chain need one or more modern and efficient pelletizing centers serving the market of industrial hops. Conversely, for small-scale hop growers, who produce their own craft beer, probably would be better to equip their breweries for the use of self-produced hop cones, in order to better transfer the "terroir" of their hop fields to their beers.

\section{Quality Aspects and Sustainable Production}

The brewing value of hops is mainly determined by the $\alpha$-acid content and composition of essential oil. Results from research aiming to characterize quality in hops cultivated under Mediterranean climatic conditions are much more numerous than those from agronomic studies [70,103-105]. This is because the craft beer sector is mainly interested to assess the "terroir" that each growing environment can impress to hops and, consequently, to beer [105]. This approach is prone to leading to a half-truth, since the chemical composition of hops is not only affected by environmental conditions but also by variety, harvesting time, pest and disease control, and other agronomic practices [2,7,106-110]. Anyway, all authors consistently showed that quality attributes and sensory features of hops grown under Mediterranean environment are similar or even better than that coming from traditional growing zones [14,70,103].

Quality in crop production is often linked to the farming system [111]. In particular, many consumers believe that organic foods are healthier and taste better, in addition to being environmental-friendly [112]. A recent survey showed that, even if the average American consumer is not willing to pay a premium price for certified organic beer, buyers who regularly drink craft beers are willing to pay more for organic beers [113]. The authors suggested that microbreweries have an additional edge on the organic beer market, because craft beer consumers are more commonly looking for new flavors and styles of beers to try. In Italy, organic certification was found to be the fourth (on thirteen) most important beer attribute for craft beer drinkers, following taste, fermentation process, and color [114]. Analyzing beer consumer perceptions and preferences along ten years, in a just published systematic review, the authors suggested that consumer perceptions of new styles of beer and speciality beers (such as sustainable or organic beer) require additional attention from 
scholars and market analysts [115]. The authors also argued that these aspects might represent factors generating differentiation strategies in the beer market for the future.

Whereas growing hop organically is an option for the large majority of hop growers, it is practically the only way to manage hopyards in new growing areas such as Italy. Currently, since no chemicals are yet registered for the protection of hops in Italy, the only discriminating factor between organic and conventional hops is the use of chemical fertilizers. Our experience suggests that growing hop under organic farming conditions is feasible in Italy, but it requires a deep knowledge of all agronomic strategies that can either limit pathogen, pest and weed pressure, or increase soil fertility without resort to chemicals. Moreover, plant requirements in different phenological phases must be precisely known to timely apply the needed agronomic practices. Currently, finding this expertise is extremely rare in small-scale Italian hop production system, since hopyard managers are often brewers or pub owners and not professional farmers. This implies that an extensive and specialized consulting system must be created to help farmers that want to face this new challenging crop. However, to accomplish this goal, adequate public and private funding must be provided for the acquisition of reliable scientific data. Otherwise, the development of hop cultivation in the Mediterranean Basin will ever remain in its early stage.

\section{Concluding Remarks and Future Perspectives}

The growing popularity of craft beer and the increasing interest in natural medicine is widening appealing scenarios for hops, even in the new growing areas of Southern Europe. However, structural constraints and absence of registered products for plant protection heavily hinder the progress of cultivation in these emerging zones. One of the biggest challenges for new hop growers is finding harvesting and processing equipment that is affordable and scaled appropriately for their activity [77].

Currently, the major knowledge gaps are at the beginning of the hop supply chain. Although some information we have about the adaptation to the Mediterranean pedo-climatic conditions of different commercial hop cultivars, the effects that agronomic practices and trellising systems have on yield and quality of hops are mostly unknown. For this reason, reliable field data urgently need to optimize hop cultivation, thus avoiding the stagnation of such a promising crop. This means that public investments should increase and support research activity and hop growers in overcoming the abovementioned limitations. The aim should be to produce a high quality hops not only for the craft beer sector but also for the pharmaceutical and food industry.

Author Contributions: Conceptualization, F.R., P.L. and R.R.; methodology, F.R., R.R. and N.I.; validation of bibliography, G.V., N.I. and M.E.P.; writing—original draft preparation, R.R. and P.L.; writing-review and editing, F.R., M.E.P., G.V. and N.I.; visualization, P.L., M.E.P., G.V. and N.I.; supervision, F.R.; project administration, F.R. and R.R.; preparation of all figures, P.L. All authors have read and agreed to the published version of the manuscript.

Funding: This research received no external funding.

Institutional Review Board Statement: Not applicable.

Informed Consent Statement: Not applicable.

Acknowledgments: The authors wish to acknowledge Ljiljana Kuzmanović for providing the Figure 1.

Conflicts of Interest: The authors declare no conflict of interest.

\section{References}

1. Small, E. A numerical and nomenclatural analysis of morpho-geographic taxa of Humulus. Syst. Bot. 1978, 3, 37-76. [CrossRef]

2. Neve, R.A. Hops; Chapman \& Hal: London, UK, 1991; ISBN 9789401053754.

3. Pignatti, S. Flora d'Italia; Edagricole-New Business Media: Devon, UK, 2017.

4. FAOSTAT. Available online: http://www.fao.org/faostat/en/\#data/QC/visualize (accessed on 2 April 2021). 
5. Carbone, K.; Macchioni, V.; Petrella, G.; Cicero, D.O. Exploring the potential of microwaves and ultrasounds in the green extraction of bioactive compounds from Humulus lupulus for the food and pharmaceutical industry. Ind. Crops Prod. 2020, 156, 112888. [CrossRef]

6. Sirrine, R.J.; Rothwell, N.; Lizotte, E.; Goldy, R.; Marquie, S.; Brown-Rytlewski, D.E. Sustainable hop production in the Great Lakes region. In Michigan State University Extension Bulletin E-3083; Michigan State University Extension: January 2010. Available online: https: / / www.uvm.edu/sites / default/ files / media/Sirrine-Sustainable-Hop-Production-in-the-Great-Lakes-Region.pdf (accessed on 23 May 2021).

7. Mozny, M.; Tolasz, R.; Nekovar, J.; Sparks, T.; Trnka, M.; Zalud, Z. The impact of climate change on the yield and quality of Saaz hops in the Czech Republic. Agric. For. Meteorol. 2009, 149, 913-919. [CrossRef]

8. Beck, H.E.; Zimmermann, N.E.; McVicar, T.R.; Vergopolan, N.; Berg, A.; Wood, E.F. Present and future köppen-geiger climate classification maps at 1-km resolution. Sci. Data 2018, 5, 180214. [CrossRef] [PubMed]

9. Pavlovic, M. Production character of the eu hop industry. Bulg. J. Agric. Sci. 2012, 18, 233-239.

10. Šrédl, K.; Prášilová, M.; Svoboda, R.; Severová, L. Hop production in the Czech Republic and its international aspects. Heliyon 2020, 6, e04371. [CrossRef]

11. Pokrivčák, J.; Supeková, S.C.; Lančarič, D.; Savov, R.; Tóth, M.; Vašina, R. Development of beer industry and craft beer expansion. J. Food Nutr. Res. 2019, 58, 63-74.

12. Bocquet, L.; Sahpaz, S.; Hilbert, J.L.; Rambaud, C.; Rivière, C. Humulus lupulus L., a very popular beer ingredient and medicinal plant: Overview of its phytochemistry, its bioactivity, and its biotechnology. Phytochem. Rev. 2018, 17, 1047-1090. [CrossRef]

13. Turner, S.F.; Benedict, C.A.; Darby, H.; Hoagland, L.A.; Simonson, P.; Robert Sirrine, J.; Murphy, K.M. Challenges and opportunities for organic hop production in the United States. Agron. J. 2011, 103, 1645-1654. [CrossRef]

14. Rossini, F.; Loreti, P.; Provenzano, M.E.; De Santis, D.; Ruggeri, R. Agronomic performance and beer quality assessment of twenty hop cultivars grown in central Italy. Ital. J. Agron. 2016, 11, 180-187. [CrossRef]

15. Bocquet, L.; Rivière, C.; Dermont, C.; Samaillie, J.; Hilbert, J.L.; Halama, P.; Siah, A.; Sahpaz, S. Antifungal activity of hop extracts and compounds against the wheat pathogen Zymoseptoria tritici. Ind. Crops Prod. 2018, 122, 290-297. [CrossRef]

16. Abram, V.; Čeh, B.; Vidmar, M.; Hercezi, M.; Lazić, N.; Bucik, V.; Možina, S.S.; Košir, I.J.; Kač, M.; Demšar, L.; et al. A comparison of antioxidant and antimicrobial activity between hop leaves and hop cones. Ind. Crops Prod. 2015, 64, 124-134. [CrossRef]

17. Alonso-Esteban, J.I.; Pinela, J.; Barros, L.; Ćirić, A.; Soković, M.; Calhelha, R.C.; Torija-Isasa, E.; de Cortes Sánchez-Mata, M.; Ferreira, I.C.F.R. Phenolic composition and antioxidant, antimicrobial and cytotoxic properties of hop (Humulus lupulus L.) seeds. Ind. Crops Prod. 2019, 134, 154-159. [CrossRef]

18. Astray, G.; Gullón, P.; Gullón, B.; Munekata, P.E.S.; Lorenzo, J.M. Humulus lupulus L. as a natural source of functional biomolecules. Appl. Sci. 2020, 10, 5074. [CrossRef]

19. Srečec, S.; Zechner-Krpan, V.; Petravič-Tominac, V.; Košir, I.; Čerenak, A. Importance of medical effects of xanthohumol, hop (Humulus lupulus L.) bioflavonoid in restructuring of world hop industry. Agric. Conspec. Sci. 2012, 77, 61-67.

20. Lukešová, H.; Andersen, H.L.; Kolínová, M.; Holst, B. Is It Hop? Identifying hop fibres in a european historical context. Archaeometry 2019, 61, 494-505. [CrossRef]

21. Nionelli, L.; Pontonio, E.; Gobbetti, M.; Rizzello, C.G. Use of hop extract as antifungal ingredient for bread making and selection of autochthonous resistant starters for sourdough fermentation. Int. J. Food Microbiol. 2018, 266, 173-182. [CrossRef]

22. Koetter, U.; Biendl, M. Hops (Humulus lupulus): A review of its historic and medicinal uses. HerbalGram 2010, 87, 46-59.

23. Dostálek, P.; Karabín, M.; Jelínek, L. Hop phytochemicals and their potential role in metabolic syndrome prevention and therapy. Molecules 2017, 22, 1761. [CrossRef]

24. Karabín, M.; Hudcová, T.; Jelínek, L.; Dostálek, P. Biologically active compounds from hops and prospects for their use. Compr. Rev. Food Sci. Food Saf. 2016, 15, 542-567. [CrossRef]

25. Zanoli, P.; Zavatti, M. Pharmacognostic and pharmacological profile of Humulus lupulus L. J. Ethnopharmacol. 2008, 116, 383-396. [CrossRef] [PubMed]

26. EMA. Hop Strobile. Available online: http://www.ema.europa.eu/docs/en_GB/document_library/Herbal_-_Summary_of_ assessment_report_for_the_public/2016/10/WC500213787.pdf (accessed on 18 April 2017).

27. Tyler, V.E. The New Honest Herbal. A Sensible Guide to Herbs and Related Remedies; G.F. Stickley Co.: Philadelphia, PA, USA, 1987.

28. Schulz, V.; Hänsel, R.; Blumenthal, M.; Tyler, V.E. Rational Phytotherapy A Reference Guide for Physicians and Pharmacists; Springer: Berlin/Heidelberg, Germany, 2004.

29. Franco, L.; Sánchez, C.; Bravo, R.; Rodriguez, A.; Barriga, C.; Juánez, J.C. The sedative effects of hops (Humulus lupulus), a component of beer, on the activity/rest rhythm. Acta Physiol. Hung. 2012, 99, 133-139. [CrossRef]

30. Schiller, H.; Forster, A.; Vonhoff, C.; Hegger, M.; Biller, A.; Winterhoff, H. Sedating effects of Humulus lupulus L. extracts. Phytomedicine 2006, 13, 535-541. [CrossRef] [PubMed]

31. Franco, L.; Sánchez, C.; Bravo, R.; Rodríguez, A.B.; Barriga, C.; Romero, E.; Cubero, J. The sedative effect of non-alcoholic beer in healthy female nurses. PLoS ONE 2012, 7, e37290. [CrossRef]

32. Chadwick, L.R.; Pauli, G.F.; Farnsworth, N.R. The pharmacognosy of Humulus lupulus L. (hops) with an emphasis on estrogenic properties. Phytomedicine 2006, 13, 119-131. [CrossRef]

33. Milligan, S.; Kalita, J.C.; Heyerick, A.; Rong, H.; De Cooman, L.; De Keukeleire, D. Identification of a potent phytoestrogen in hops (Humulus lupulus L.) and beer. J. Clin. Endocrinol. Metab. 1999, 83, 2249-2252. [CrossRef] [PubMed] 
34. Verzele, M. Centenary review-100 years of hop chemistry and its relevance to brewing. J. Inst. Brew. 1986, 92, 32-48. [CrossRef]

35. Milligan, S.; Kalita, J.C.; Pocock, V.; Van de Kauter, V.; Stevens, J.F.; Deinzer, M.L.; Rong, H.; De Keukeleire, D. The endocrine activities of 8-prenylnaringenin and related hop (Humulus lupulus L.) flavonoids. J. Clin. Endocrinol. Metab. 2000, 85, $4912-4915$. [CrossRef]

36. Karabin, M.; Hudcova, T.; Jelinek, L.; Dostalek, P. Biotransformations and biological activities of hop flavonoids. Biotechnol. Adv. 2015, 33, 1063-1090. [CrossRef] [PubMed]

37. Aichinger, G.; Beisl, J.; Marko, D. The hop polyphenols xanthohumol and 8-prenyl-naringenin antagonize the estrogenic effects of fusarium mycotoxins in human endometrial cancer cells. Front. Nutr. 2018, 5, 85. [CrossRef]

38. Tronina, T.; Popłonski, J.; Bartmanska, A. Flavonoids as phytoestrogenic components of hops and beer. Molecules 2020, $25,4201$. [CrossRef]

39. Wang, S.; Dunlap, T.L.; Howell, C.E.; Mbachu, O.C.; Rue, E.A.; Phansalkar, R.; Chen, S.N.; Pauli, G.F.; Dietz, B.M.; Bolton, J.L. Hop (Humulus lupulus L.) extract and 6-prenylnaringenin induce P450 1A1 catalyzed estrogen 2-hydroxylation. Chem. Res. Toxicol. 2016, 29, 1142-1150. [CrossRef]

40. Bocquet, L.; Sahpaz, S.; Bonneau, N.; Beaufay, C.; Mahieux, S.; Samaillie, J.; Roumy, V.; Jacquin, J.; Bordage, S.; Hennebelle, T.; et al. Phenolic compounds from Humulus lupulus as natural antimicrobial products: New weapons in the fight against methicillin resistant Staphylococcus aureus, Leishmania mexicana and Trypanosoma brucei strains. Molecules 2019, 24, 1024. [CrossRef]

41. Arruda, T.R.; Pinheiro, P.F.; Silva, P.I.; Bernardes, P.C. A new perspective of a well-recognized raw material: Phenolic content, antioxidant and antimicrobial activities and $\alpha$ - and $\beta$-acids profile of Brazilian hop (Humulus lupulus L.) extracts. LWT Food Sci. Technol. 2021, 141, 110905. [CrossRef]

42. Kontek, B.; Jedrejek, D.; Oleszek, W.; Olas, B. Antiradical and antioxidant activity in vitro of hops-derived extracts rich in bitter acids and xanthohumol. Ind. Crops Prod. 2021, 161, 113208. [CrossRef]

43. Hege, M.; Jung, F.; Sellmann, C.; Jin, C.; Ziegenhardt, D.; Hellerbrand, C.; Bergheim, I. An iso- $\alpha$-acid-rich extract from hops (Humulus lupulus) attenuates acute alcohol-induced liver steatosis in mice. Nutrition 2018, 45, 68-75. [CrossRef]

44. Ponticelli, M.; Russo, D.; Faraone, I.; Sinisgalli, C.; Labanca, F.; Lela, L.; Milella, L. The promising ability of Humulus lupulus L. Iso- $\alpha$-acids vs. diabetes, inflammation, and metabolic syndrome: A systematic review. Molecules 2021, 26, 954. [CrossRef]

45. Edwardson, J.R. Hops: Their botany, history, production and utilization. Econ. Bot. 1952, 6, 160-175. [CrossRef]

46. Kopp, P.A. The global hop: An agricultural overview of the brewer's gold. In The Geography of Beer; Patterson, M.W., Pullen, N.H., Eds.; Springer: Dordrecht, The Netherlands, 2014; pp. 77-88. ISBN 978-94-007-7786-6.

47. Almaguer, C.; Schönberger, C.; Gastl, M.; Arendt, E.K.; Becker, T. Humulus lupulus-A story that begs to be told. A review. J. Inst. Brew. 2014, 120, 289-314. [CrossRef]

48. Patzak, J.; Krofta, K.; Henychová, A.; Nesvadba, V. Number and size of lupulin glands, glandular trichomes of hop (Humulus lupulus L.), play a key role in contents of bitter acids and polyphenols in hop cone. Int. J. Food Sci. Technol. 2015, 50, 1864-1872. [CrossRef]

49. Aquilani, B.; Laureti, T.; Poponi, S.; Secondi, L. Beer choice and consumption determinants when craft beers are tasted: An exploratory study of consumer preferences. Food Qual. Prefer. 2015, 41, 214-224. [CrossRef]

50. Calvo-Porral, C.; Rivaroli, S.; Orosa-Gonzalez, J. How consumer involvement influences beer flavour preferences. Int. J. Wine Bus. Res. 2020, 32, 537-554. [CrossRef]

51. Haunold, A.; Nickerson, G. Factors Affecting Hop Production, Hop Quality, and Brewer Preference. Available online: https: //www.morebeer.com/articles/factors_affecting_hop_production (accessed on 22 February 2021).

52. Sanchez-Mata, M.C.; Cabrera Loera, R.D.; Morales, P.; Fernandez-Ruiz, V.; Camara, M.; Diez Marqués, C.; Pardo-de-Santayana, M.; Tardio, J. Wild vegetables of the Mediterranean area as valuable sources of bioactive compounds. Genet. Resour. Crop Evol. 2012, 59, 431-443. [CrossRef]

53. Tardío, J.; de Cortes Sánchez-Mata, M.; Morales, R.; Molina, M.; García-Herrera, P.; Morales, P.; Díez-Marqués, C.; Fernández-Ruiz, V.; Cámara, M.; Pardo-de-Santayana, M.; et al. Ethnobotanical and food composition monographs of selected mediterranean wild edible plants. In Mediterranean Wild Edible Plants_Ethnobotany and Food Composition Tables; de Cortes Sánchez-Mata, M., Tardío, J., Eds.; Springer: New York, NY, USA, 2016; p. 478.

54. Rossini, F.; Virga, G.; Loreti, P.; Provenzano, M.E.; Danieli, P.P.; Ruggeri, R. Beyond beer: Hop shoot production and nutritional composition under mediterranean climatic conditions. Agronomy 2020, 10, 1547. [CrossRef]

55. Vidmar, M.; Čeh, B.; Demšar, L.; Ulrih, N.P. White hop shoot production in Slovenia: Total phenolic, microelement and pesticide residue content in five commercial cultivars. Food Technol. Biotechnol. 2019, 57, 525-534. [CrossRef]

56. Bedini, S.; Flamini, G.; Cosci, F.; Ascrizzi, R.; Benelli, G.; Conti, B. Cannabis sativa and Humulus lupulus essential oils as novel control tools against the invasive mosquito Aedes albopictus and fresh water snail Physella acuta. Ind. Crops Prod. 2016, 85, 318-323. [CrossRef]

57. Bedini, S.; Flamini, G.; Girardi, J.; Cosci, F.; Conti, B. Not just for beer: Evaluation of spent hops (Humulus lupulus L.) as a source of eco-friendly repellents for insect pests of stored foods. J. Pest. Sci. 2015, 88, 583-592. [CrossRef]

58. Iglesias, A.; Mitton, G.; Szawarski, N.; Cooley, H.; Ramos, F.; Meroi Arcerito, F.; Brasesco, C.; Ramirez, C.; Gende, L.; Eguaras, M.; et al. Essential oils from Humulus lupulus as novel control agents against Varroa destructor. Ind. Crops Prod. 2020, 158, 113043. [CrossRef] 
59. Kramer, B.; Thielmann, J.; Hickisch, A.; Muranyi, P.; Wunderlich, J.; Hauser, C. Antimicrobial activity of hop extracts against foodborne pathogens for meat applications. J. Appl. Microbiol. 2015, 118, 648-657. [CrossRef]

60. Larson, A.E.; Yu, R.R.Y.; Lee, O.A.; Price, S.; Haas, G.J.; Johnson, E.A. Antimicrobial activity of hop extracts against Listeria monocytogenes in media and in food. Int. J. Food Microbiol. 1996, 33, 195-207. [CrossRef]

61. Rossbauer, G.; Buhr, L.; Hack, H.; Hauptmann, S.; Klose, R.; Meier, U.; Stauss, R.; Weber, E. Phänologische Entwicklungsstadien von Kultur-Hopfen (Humulus lupulus L.). Nachrichtenbl. Deut. Pflanzenschutzd. 1995, 47, 249-253.

62. Marceddu, R.; Carrubba, A.; Sarno, M. Cultivation trials of hop (Humulus lupulus L.) in semi-arid environments. Heliyon 2020, 6, e05114. [CrossRef]

63. Ruggeri, R.; Loreti, P.; Rossini, F. Exploring the potential of hop as a dual purpose crop in the Mediterranean environment: Shoot and cone yield from nine commercial cultivars. Eur. J. Agron. 2018, 93, 11-17. [CrossRef]

64. Krebs, C. Hops: A viable alternative crop for the central/southern plains? Crop. Soils 2019, 52, 4-6. [CrossRef]

65. Afonso, S.; Arrobas, M.; Rodrigues, M.Â. Soil and plant analyses to diagnose hop fields irregular growth. J. Soil Sci. Plant Nutr. 2020, 20, 1999-2013. [CrossRef]

66. Jezek, J.; Krivánek, J.; Pokorný, J. Trials with growing hops on low trellis in the czech republic in 2009-2011. Acta Hortic. 2013, 1010, 199-203. [CrossRef]

67. Campbell, C.A.M. Influence of companion planting on damson hop aphid Phorodon humuli, two spotted spider mite Tetranychus urticae, and their antagonists in low trellis hops. Crop Prot. 2018, 114, 23-31. [CrossRef]

68. IHGC (International Hop Growers' Convention). Available online: http://www.hmelj-giz.si/ihgc/obj.htm (accessed on 2 April 2021).

69. Mongelli, A.; Rodolfi, M.; Ganino, T.; Marieschi, M.; Dall'Asta, C.; Bruni, R. Italian hop germplasm: Characterization of wild Humulus lupulus L. genotypes from Northern Italy by means of phytochemical, morphological traits and multivariate data analysis. Ind. Crops Prod. 2015, 70, 16-27. [CrossRef]

70. Mongelli, A.; Rodolfi, M.; Ganino, T.; Marieschi, M.; Caligiani, A.; Dall'Asta, C.; Bruni, R. Are Humulus lupulus L. ecotypes and cultivars suitable for the cultivation of aromatic hop in Italy? A phytochemical approach. Ind. Crops Prod. 2016, 83, 693-700. [CrossRef]

71. Peredo, E.L.; Arroyo-García, R.; Revilla, M.Á. Epigenetic changes detected in micropropagated hop plants. J. Plant Physiol. 2009, 166, 1101-1111. [CrossRef]

72. Postman, J.D.; DeNoma, J.S.; Reed, B.M. Detection and elimination of viruses in USDA hop (Humulus lupulus) germoplasm collection. Acta Hortic. 2005, 668, 143-148. [CrossRef]

73. Reed, B.M.; Okut, N.; D’Achino, J.; Narver, L.; DeNoma, J. Cold storage and cryopreservation of hops (Humulus L.) shoot cultures through application of standard protocols. Cryo Lett. 2003, 24, 389-396.

74. Gurriarán, M.J.; Revilla, M.A.; Tamés, R.S. Adventitious shoot regeneration in cultures of Humulus lupulus L. (hop) cvs. Brewers gold and nugget. Plant Cell Rep. 1999, 18, 1007-1011. [CrossRef]

75. Brant, V.; Krofta, K.; Kroulík, M.; Zábranský, P.; Procházka, P.; Pokorný, J. Distribution of root system of hop plants in hop gardens with regular rows cultivation. Plant Soil Environ. 2020, 66, 317-326. [CrossRef]

76. Kořen, J. Influence of plantation row spacing on quality and yield of hops. Plant Soil Environ. 2007, 53, 276-282. [CrossRef]

77. Dodds, K. Hops-A Guide for New Growers; NSW Department of Primary Industries: Orange, NSW, Australia, 2017; ISBN 978-1-76058-007-0.

78. Gent, D.H.; Nelson, M.E.; Grove, G.G.; Mahaffee, W.F.; Turechek, W.W.; Woods, J.L. Association of spring pruning practices with severity of powdery mildew and downy mildew on hop. Plant Dis. 2012, 96, 1343-1351. [CrossRef]

79. Probst, C.; Nelson, M.E.; Grove, G.G.; Twomey, M.C.; Gent, D.H. Hop powdery mildew control through alteration of spring pruning practices. Plant Dis. 2016, 100, 1599-1605. [CrossRef]

80. Rybacek, V. Hop Production, 1st ed.; Elsevier Science: Amsterdam, The Netherlands, 1991; ISBN 9780444987709.

81. Fandino, M.; Olmedo, J.L.; Martinez, E.M.; Valladares, J.; Paredes, P.; Rey, B.J.; Mota, M.; Cancela, J.J.; Pereira, L.S. Assessing and modelling water use and the partition of evapotranspiration of irrigated hop (Humulus lupulus), and relations of transpiration with hops yield and alpha-acids. Ind. Crops Prod. 2015, 77, 204-217. [CrossRef]

82. Nakawuka, P.; Peters, T.R.; Kenny, S.; Walsh, D. Effect of deficit irrigation on yield quantity and quality, water productivity and economic returns of four cultivars of hops in the Yakima Valley, Washington State. Ind. Crops Prod. 2017, 98, 82-92. [CrossRef]

83. Gloser, V.; Baláz, M.; Jupa, R.; Korovetska, H.; Svoboda, P. The response of Humulus lupulus to drought: The contribution of structural and functional plant traits. Acta Hortic. 2013, 1010, 149-154. [CrossRef]

84. Potopová, V.; Lhotka, O.; Možný, M.; Musiolková, M. Vulnerability of hop-yields due to compound drought and heat events over European key-hop regions. Int. J. Climatol. 2021, 41, E2136-E2158. [CrossRef]

85. Bavec, F.; Čeh Brežnik, B.; Brežnik, M. Hop yield evaluation depending on experimental plot area under different nitrogen management. Plant Soil Environ. 2003, 49, 163-167. [CrossRef]

86. Senske, A.M. Optimization of N Fertilization for Hops (Humulus lupulus) in Iowa Soils; Iowa State University: Ames, IA, USA, 2020.

87. Gingrich, C.; Hart, J.; Christensen, N. Hops. In Fertilizer Guide 79; OSU-Extension Service: Corvallis, OR, USA, 2000.

88. Čeh, B. Impact of slurry on the hop (Humulus lupulus L.) yield, its quality and n-min content of the soil. Plant Soil Environ. 2014, 60, 267-273. [CrossRef] 
89. Pang, X.P.; Letey, J. Organic farming challenge of timing nitrogen availability to crop nitrogen requirements. Soil Sci. Soc. Am. J. 2000, 64, 247-253. [CrossRef]

90. Rossini, F.; Provenzano, M.E.; Sestili, F.; Ruggeri, R. Synergistic effect of sulfur and nitrogen in the organic and mineral fertilization of durum wheat: Grain yield and quality traits in the Mediterranean environment. Agronomy 2018, 8, 189. [CrossRef]

91. Kirkland, K.J.; Beckie, H.J. Contribution of nitrogen fertilizer placement to weed management in spring wheat (Triticum aestivum) Weed Technol. 1998, 12, 507-514. [CrossRef]

92. Sirrine, R. The Importance of Testing Hop Fertility. Available online: https://www.canr.msu.edu/news/the_importance_of_ testing_hop_fertility (accessed on 2 April 2021).

93. Procházka, P.; Štranc, P.; Pazderů, K.; Vostřel, J.; Řehoř, J. Use of biologically active substances in hops. Plant Soil Environ. 2018, 64, 626-632. [CrossRef]

94. Jakse, J.; Radisek, S.; Pokorn, T.; Matousek, J.; Javornik, B. Deep-sequencing revealed Citrus bark cracking viroid (CBCVd) as a highly aggressive pathogen on hop. Plant Pathol. 2015, 64, 831-842. [CrossRef]

95. Gargani, E.; Ferretti, L.; Faggioli, F.; Haegi, A.; Luigi, M.; Landi, S.; Simoni, S.; Benvenuti, C.; Guidi, S.; Simoncini, S.; et al. A survey on pests and diseases of Italian hop crops. Italus Hortus 2018, 24, 1-17. [CrossRef]

96. Matoušek, J.; Siglová, K.; Jakše, J.; Radišek, S.; Brass, J.R.J.; Tsushima, T.; Guček, T.; Duraisamy, G.S.; Sano, T.; Steger, G. Propagation and some physiological effects of Citrus bark cracking viroid and Apple fruit crinkle viroid in multiple infected hop (Humulus lupulus L.). J. Plant Physiol. 2017, 213, 166-177. [CrossRef] [PubMed]

97. Štajner, N.; Radišek, S.; Mishra, A.K.; Nath, V.S.; Matoušek, J.; Jakše, J. Evaluation of disease severity and global transcriptome response induced by Citrus bark cracking viroid, Hop latent viroid, and their co-infection in hop (Humulus lupulus L.). Int. J. Mol. Sci. 2019, 20, 3154. [CrossRef]

98. European and Mediterranean Plant Protection Organization. PM 9/21(1) Popillia japonica: Procedures for official control. EPPO Bull. 2016, 46, 543-555. [CrossRef]

99. Lipecki, J.; Berbeć, S. Soil management in perennial crops: Orchards and hop gardens. Soil Tillage Res. 1997, 43, 169-184. [CrossRef]

100. Delahunty, K.M.; Johnston, J.C. Strategies for weed management in organic hops, a perennial crop. Agron. J. 2015, 107, 634-640. [CrossRef]

101. Scarici, E.; Ruggeri, R.; Provenzano, M.E.; Rossini, F. Germination and performance of seven native wildflowers in the Mediterranean landscape plantings. Ital. J. Agron. 2018, 13, 163-171. [CrossRef]

102. HVG. Pellets. Available online: https://hvg-germany.de/en/hop-processing/hop-pellets (accessed on 2 April 2021).

103. Forteschi, M.; Porcu, M.C.; Fanari, M.; Zinellu, M.; Secchi, N.; Buiatti, S.; Passaghe, P.; Bertoli, S.; Pretti, L. Quality assessment of Cascade Hop (Humulus lupulus L.) grown in Sardinia. Eur. Food Res. Technol. 2019, 245, 863-871. [CrossRef]

104. Mozzon, M.; Foligni, R.; Mannozzi, C. Brewing quality of hop varieties cultivated in central Italy based on multivolatile fingerprinting and bitter acid content. Foods 2020, 9, 541. [CrossRef]

105. Rodolfi, M.; Chiancone, B.; Liberatore, C.M.; Fabbri, A.; Cirlini, M.; Ganino, T. Changes in chemical profile of Cascade hop cones according to the growing area. J. Sci. Food Agric. 2019, 99, 6011-6019. [CrossRef]

106. Matsui, H.; Inui, T.; Oka, K.; Fukui, N. The influence of pruning and harvest timing on hop aroma, cone appearance, and yield. Food Chem. 2016, 202, 15-22. [CrossRef]

107. Inui, T.; Okumura, K.; Matsui, H.; Hosoya, T.; Kumazawa, S. Effect of harvest time on some in vitro functional properties of hop polyphenols. Food Chem. 2017, 225, 69-76. [CrossRef]

108. Mackinnon, D.; Pavlovič, V.; Čeh, B.; Naglič, B.; Pavlovič, M. The impact of weather conditions on alpha-acid content in hop (Humulus lupulus L.) cv. Aurora. Plant Soil Environ. 2020, 66, 519-525. [CrossRef]

109. Lafontaine, S.; Caffrey, A.; Dailey, J.; Varnum, S.; Hale, A.; Eichler, B.; Dennenlöhr, J.; Schubert, C.; Knoke, L.; Lerno, L.; et al Evaluation of variety, maturity, and farm on the concentrations of monoterpene diglycosides and hop volatile/nonvolatile composition in five Humulus lupulus Cultivars. J. Agric. Food Chem. 2021, 69, 4356-4370. [CrossRef] [PubMed]

110. De Keukeleire, J.; Janssens, I.; Heyerick, A.; Ghekiere, G.; Cambie, J.; Roldán-Ruiz, I.; Van Bockstaele, E.; De Keukeleire, D. Relevance of organic farming and effect of climatological conditions on the formation of $\alpha$-acids, $\beta$-acids, desmethylxanthohumol, and xanthohumol in hop (Humulus lupulus L.). J. Agric. Food Chem. 2007, 55, 61-66. [CrossRef] [PubMed]

111. Reeve, J.; Hoagland, L.; Villalba, J.J.; Carr, P.M.; Atucha, A.; Cambardella, C.; Davis, D.R.; Delate, K. Organic farming, soil health, and food quality: Considering possible links. In Advances in Agronomy; Sparks, D.L., Ed.; Academic Press: Cambridge, MA, USA, 2016; pp. 319-367.

112. Monier-Dilhan, S.; Bergès, F. Consumers' motivations driving organic demand: Between selfinterest and sustainability. Agric. Resour. Econ. Rev. 2016, 45, 522-538. [CrossRef]

113. Waldrop, M.E.; McCluskey, J.J. Does information about organic status affect consumer sensory liking and willingness to pay for beer? Agribusiness 2019, 35, 149-167. [CrossRef]

114. Lerro, M.; Marotta, G.; Nazzaro, C. Measuring consumers' preferences for craft beer attributes through Best-Worst Scaling. Agric. Food Econ. 2020, 8, 1. [CrossRef]

115. Capitello, R.; Todirica, I.C. Understanding the behavior of beer consumers. In Case Studies in the Beer Sector; Capitello, R., Maehle, N., Eds.; Elsevier Inc.: Amsterdam, The Netherlands, 2021; pp. 15-36. 